Marquette University

e-Publications@Marquette

College of Education Faculty Research and

Publications

Education, College of

$3-1-2008$

\title{
Gifts in Psychotherapy: Practice Review and Recommendations
}

Sarah Knox

Marquette University, sarah.knox@marquette.edu

Accepted version. Psychotherapy Theory, Research, Practice, Training, Vol. 45, No. 1 (March 2008): 103-110. DOI. (C) 2008 American Psychological Association. Used with permission.

This article may not exactly replicate the final version published in the APA journal. It is not the copy of record. 


\title{
Gifts in Psychotherapy: Practice Review and Recommendations
}

\author{
Sarah Knox \\ Department of Counseling and Educational Psychology, School of \\ Education, Marquette University \\ Milwaukee, WI
}

\begin{abstract}
The presentation of gifts in psychotherapy, whether to or from the therapist, does not happen frequently, but its occurrence may nevertheless be quite provocative. This practice review summarizes theoretical and clinical perspectives regarding gifts in therapy, reviews the minimal extant literature on this topic, and offers recommendations for practice and research.
\end{abstract}

The giving and receiving of gifts in therapy is a topic about which mental health professionals have periodically offered their opinions, usually doing so in the context of their own clinical experiences. Despite the presence of these assertions regarding appropriate gift-related conduct in therapy, there is surprisingly little empirical research in this area. In addition, the bulk of both opinion and research has focused on gifts to therapists from adult clients in individual therapy. Gifts from therapists to clients; from nonadult clients; or from clients in group, couples, or family therapy, however, have received less attention. Furthermore, the current version of the American Psychological Association Ethical Code (APA, 2002) does not directly address gifts in therapy, and therefore provides no specific guidance for ethical practice in this area. It seems prudent, then, to 
examine what we know... and also, what we still need to know... regarding gifts in therapy, so that such events may be managed most helpfully. In this paper, after having comprehensively examined the literature that specifically addressed gifts in therapy, I first thematically summarize existing theoretical and clinical perspectives. I then describe the extant empirical work regarding gifts in therapy, based also on a comprehensive review of the research in this area. I conclude with practice and research recommendations.

\section{Theoretical and Clinical Perspectives Regarding Gifts in Psychotherapy}

Consistent with existing opinion and empirical literature (see below), gifts are defined here as tangible objects given by one person to another. Among the earliest references to gifts in therapy is Freud's (1917) acknowledgment that gift-giving both from and to the client may occur, and that such gifts have unconscious meaning. Gifts likely hold conscious meaning, as well (Bursten, 1959). In this way, giftgiving serves as a symbolic communication between giver and recipient to create or strengthen the bond between them, but this communication via behavior (i.e., giving the gift) rather than words heightens the chances of misunderstanding (Ruth, 1996). Furthermore, in giving a gift, the giver expects a response from the receiver (Stein, 1965).

\section{General Themes}

The prevailing consensus regarding gifts in therapy may be summarized as "be careful," whether in reference to gifts from/to therapists/clients, for such interactions are deemed to stretch the therapy boundaries (Hundert, 1998). Knapp and VandeCreek (2006) provide an effective overview of what they offer as therapeutic responses to gifts. First, therapists' most appropriate attitude about gifts should be to focus on clients' welfare. Some therapists reject all gifts and instead use their offering as an opportunity to discuss the implications of the gift for the therapy relationship. Most therapists, however, likely accept nominal gifts with an appropriate expression of appreciation, and consider the event simply a courteous social convention. Accepting such gifts affirms clients and promotes their 
self-acceptance, whereas refusal would activate defenses that inhibit self-reflection and self-understanding (Hahn, 1998).

From a more conservative perspective, gifts are viewed as unconsciously motivated representations of symbolic desires (e.g., to please the therapist, be more intimate with the therapist outside of therapy), desires that clients experience as positive feelings toward the therapist (Kritzberg, 1980). In this acting out of transference, gifts reflect clients' personality characteristics and interpersonal problems. As such, understanding the desire to give the gift is crucial to therapy, as is understanding the gift's properties (form, shape, color, design, price, value, function, timing, manner in which given) (Kritzberg, 1980). In addition, the analysis of the gift's meaning ideally leads clients to withdraw the gift, and if not, therapists should nevertheless refuse the gift, for acceptance represents a special gratification or "shared corruption" (p. 157) of appropriate boundaries that may undermine therapy and lead to further similar transgressions (e.g., additional gift offerings; Langs, 1974). Thus, the only direct material reward therapists are to receive from clients is payment for their services (Simon, 1989). Such a view is softened at times, however, for as Stein (1965) notes, the general rule is that analysts should not accept client gifts, but should also know when to make an exception. When a client who has difficulty giving anything to anyone, for instance, is finally able to give the analyst a small gift, refusal could be damaging.

According to Herlihy and Corey (1997), therapists need to consider the client's motivation for giving a gift, as well as the status of the therapy relationship: Gifts seemingly intended to manipulate therapists are probably best refused, whereas rejection of a gift intended to convey a client's appreciation may harm the relationship. They further note that acceptance of some gifts (e.g., stock tip) may always be inappropriate, and that it may be prudent to have a written policy regarding gifts as part of the materials given to clients when first entering therapy. Other important considerations regarding therapists' responses to a client's gift include the client's diagnosis (e.g., those involving boundary disturbances may warrant particular care regarding gifts), worth of the gift (e.g., less valuable gifts may be more easily accepted), the stage and length of therapy (e.g., gifts at the end of long-term therapy may be more acceptable), as well as the

Psychotherapy: Theory, Research, Practice, Training, Vol. 45, No. 1 (March 2008): pg. 103-110. DOI. This article is (C) American Psychological Association and permission has been granted for this version to appear in e-

Publications@Marquette. American Psychological Association does not grant permission for this article to be further copied/distributed or hosted elsewhere without the express permission from American Psychological Association. 
therapist's motivations (e.g., strengthen the therapy relationship, respect client cultural norms regarding gifts) for accepting or refusing the gift (Gabbard, 1996; Herlihy \& Corey, 1997). Hundert (1998) acknowledged additional factors worthy of consideration in responding to gifts: Intimate or sexual gifts should likely be refused, those of great emotional value (e.g., picture of dead fiancé) are admittedly problematic, and seemingly benign gifts (e.g., holiday fruitcake) may be more easily accepted than less benign offerings (e.g., TV set).

\section{Special Populations}

Appropriate responses to client gifts may also be affected by characteristics of the giver. Gifts from nonadult clients, for example, may warrant additional consideration, for what is "proper" for adults may not be proper for children and adolescents (Hundert \& Appelbaum, 1995). Whereas adults may be able to work through a therapist's refusal of a gift, children may have greater difficulty doing so, and thus such refusal may be more damaging to the therapy.

Responses to gifts from clients in group therapy may also require flexibility. When someone terminates from a group, other members may have difficulty tolerating their feelings related to the leaving, and they thus may seek to act in some way as a reflection of those emotions. Such action may take the form of a gift, whether to or from the terminating member(s), an exchange in which the therapist is often included. Although there is no clear rule about whether to accept gifts from terminating group members (Rutan \& Stone, 2001), such gifts require examination (Shapiro \& Ginzberg, 2002). If the gift represents the terminating member's fear that without a physical reminder, s/he will be forgotten by the therapist and the rest of the group, it may be prudent to discuss but ultimately refuse the gift. On the other hand, if the gift symbolizes the member's desire to commemorate the therapy experience, refusal of such a gift may be hurtful (Rutan \& Stone, 2001). Therapists should also consider who initiated the termination gift process, whether all members participated in its planning, and whether the process reflects the work that the departing client(s) sought to address in therapy (Shapiro \& Ginzberg, 2002). Finally, therapists are reminded that in giving a gift, clients acknowledge by action rather than words their attachment to

Psychotherapy: Theory, Research, Practice, Training, Vol. 45, No. 1 (March 2008): pg. 103-110. DOI. This article is (C) American Psychological Association and permission has been granted for this version to appear in e-

Publications@Marquette. American Psychological Association does not grant permission for this article to be further copied/distributed or hosted elsewhere without the express permission from American Psychological Association. 
other members, an approach that may provide additional fodder for the therapy itself (Smith \& Vannicelli, 1985).

Herlihy and Corey (1997) also note that gifts have different meanings in different cultures, and thus therapists must consider clients' cultures when responding to a gift. Sue and Zane (1987), for example, assert that gift-giving is common and culturally appropriate in many Asian communities to show gratitude, respect, and the sealing of a relationship. Were therapists even politely to refuse such a gift, they may unknowingly insult the giver.

\section{Other Considerations}

Worthy of comment, as well, are gifts from therapists to clients. Although Langs (1974) asserted that except in the treatment of children, concrete gifts should never pass from therapist to client, Freud provided meals to Rat Man (Gutheil \& Gabbard, 1993), and after hearing that one of his patients planned to buy a set of Freud's complete works, Freud gave the patient a set as a gift (Blanton, 1971). Immediately after doing so, the patient became unable to use his dreams effectively in analysis, which Freud attributed to the gift. In addition, the simple offering of a tissue to a crying client may often be appropriate, but in one case led to difficulty: After the client took the tissue from its leather case, the therapist impulsively asked the client to keep the case. In later supervision, the therapist realized that this offer was an unconscious bribe to avert the client's anger that lay immediately below her sorrow (Gutheil \& Gabbard, 1993). On the other hand, gifts to clients of educational texts may foster clients' mastery of their illness, and medication samples given to poor clients may likewise prove helpful (Gutheil \& Gabbard, 1993). Small gifts of minimal value given to child/adolescent clients may help establish the therapy relationship, reward therapy goals, serve as transitional objects (Levin \& Wermer, 1966), or convey respect and liking (Talan, 1989). Gifts marking important client events (e.g., wedding, birth of child) should likewise not be of substantial value nor of an intimate nature (Hundert, 1998). In the context of family therapy, Roberts (1989) gave the members of a family a t-shirt with a therapeutically relevant phrase on it in appreciation for the gift of working with them in therapy. 
An additional consideration is what to do with an accepted gift. Some therapists choose to keep client gifts in their office, but because no gift is truly anonymous, others put them in a place where other clients will not see them (Gartrell, 1992, 1994).

Thus, a range of opinion exists regarding therapists' proper response to client gifts. Even those who support acceptance of certain types of gifts under certain circumstances encourage care and consideration when doing so, and many also suggest that discussion of the gift and its meaning may be fruitful for the therapy. Gifts from nonadult clients may warrant different responses than those from adult clients, as may those from clients in group therapy or from different cultures. Gifts from therapists to clients require care, as well, as do therapists' decisions regarding what to do with accepted gifts.

\section{Empirical Research Regarding Gifts in Psychotherapy}

Since Freud's early remarks about gifts in therapy, there have appeared strikingly few published empirical examinations of this phenomenon. In fact, only six were found in preparation for this paper, each of which is discussed below. It is important to note, however, the difficulty of studying such processes. Were researchers to ask therapists prospectively about gift experiences in therapy, doing so may well alter therapist behavior; likewise, asking therapists retrospectively relies on their memory of such events. Perhaps such challenges help explain the dearth of research in this area.

In 1938, Glover (1955) distributed a written questionnaire to 29 practicing British psychoanalysts to assess their degree of agreement on "psycho-analytic technique" (p. 265), one question of which addressed gifts ("Do you accept presents from patients? If so, on what system?"). According to the 24 individuals who responded, none accepted large gifts or money offerings, and the majority did "not receive gifts gladly" (p. 319). They usually analyzed patients' motives for giving gifts, in the hope of reducing such behaviors. Intriguingly, one respondent believed that gifts were a sign of countertransference (the therapist had somehow stimulated the gift), while another posited that "few gifts" indicated some type of failing or defect in the analyst.

Psychotherapy: Theory, Research, Practice, Training, Vol. 45, No. 1 (March 2008): pg. 103-110. DOI. This article is (C) American Psychological Association and permission has been granted for this version to appear in e-

Publications@Marquette. American Psychological Association does not grant permission for this article to be further copied/distributed or hosted elsewhere without the express permission from American Psychological Association. 
Although Glover's findings are not surprising, this study presents several limitations. For example, he provided very little information regarding both sample characteristics and data analysis. The sample itself was also quite small and specific (i.e., practitioners of one orientation from one country). It is difficult to know to what extent these findings would apply to nonpsychoanalysts, to practitioners outside Britain, or to practicing professionals today.

In surveying members of APAs Division 29 (Psychotherapy) about the degree to which they engaged in each of 83 different behaviors and the extent to which they deemed such behaviors ethical, Pope, Tabachnick, and Keith-Spiegel (1987) and Borys and Pope (1989) included a few items specifically addressing gifts in therapy. Therapists almost universally accepted gifts worth less than $\$ 5$, but the majority never accepted gifts worth more than $\$ 50$. Accepting a gift worth under $\$ 10$ was considered ethical under some or most conditions by $78 \%$ of the respondents; however, most respondents ( $82 \%$ ) deemed accepting a gift worth more than $\$ 50$ as never ethical or as ethical only in rare conditions. Rarely did therapists give gifts worth at least $\$ 50$ to clients. These two studies are helpful in providing some perspective on therapists' behavior and perceptions of ethicality regarding gifts. Unfortunately, however, they employed a rather nonspecific approach, for therapists were asked only broadly about "clients" in general. We thus have no way of knowing what types of clients (e.g., age; gender; race, ethnicity, culture; diagnosis; individual, couples, family, group therapy) therapists had in mind when responding to the items, and as a result do not know to what extent, if any, their responses may change in light of such considerations.

Gerson and Fox (1999) distributed a 24-item questionnaire examining minor violations of dual relationship prohibitions to 600 forensic professionals (MA, MD, MSW, PhD, PsyD) whose work addressed aspects of the law (e.g., civil, competency, criminal, custody, workplace); the researchers received 178 responses. Six of the questions addressed gift-related concerns (e.g., offering or accepting food or a gift on a birthday, giving "vacation trinkets" to a patient, accepting tickets for an event from a patient who can't attend). Only one gift-related item (i.e., accepting a cupcake on a patient's birthday) was rated in the neutral range ("no strong 
opinion"); all other gift-related items were disapproved either somewhat or absolutely. Furthermore, no differences were found among the different professions, nor across gender and years of experience. The authors asserted that, in contrast to earlier work (e.g., Borys \& Pope, 1989), this more recent sample considered even apparently minor (gift-related) boundary violations less acceptable. Gerson and Fox's work depicts these forensic professionals' thoughts about gifts, but also presents limitations. It is possible that the respondents' specific domain of work (i.e., as forensic professionals) creates a unique context for gift-related behavior, so again the question of generalizability emerges. In addition, their questions did not operationalize important components (i.e., what is a "small" gift? tickets to what type of event and at what value?). In addition, as was the case with Pope et al. (1987) and Borys and Pope (1989), we do not know what types of clients these respondents had in mind when answering the questions.

In Spandler, Burman, Goldberg, Margison, and Amos (2000), 80 British therapists (many of whom were psychoanalytic) completed a qualitative, open-ended, written survey on giving and receiving gifts in therapy. Common gifts were food and alcohol, flowers, books, and hand-made items; most were small and inexpensive; those deemed appropriate were not too personal (e.g., intimate) and adhered to social conventions of gifts. Spandler et al. found that the timing of a gift affected how it was received (those given during therapy were perceived as more problematic than those at termination), as did its cost (excessively expensive gifts were usually rejected or kept on hold and revisited at the end of therapy). Most gifts were given by female clients, and therapists seldom addressed cultural or racial components of the gift-giving process. Many gifts appeared to express a client's wish that the therapist enjoy something the client found difficult (e.g., food from a client with an eating disorder); others seemed an expression of clients' depression or suicidal feelings (e.g., dead flowers). Upon receiving the gift, therapists experienced mixed emotions (felt awkward but pleased, were disappointed by cheapness of gift); most gifts were accepted, but large expensive gifts were often refused after they had been explored in therapy. Based on their findings, Spandler et al. concluded that (a) both acceptance and refusal of a gift can cause harm, as can overinterpretation; (b) however, gifts can also be positive and therapeutic experiences; (c) 
more benefit may accrue by attending to the significance within therapy of the meanings surrounding the giving and receiving of the gift [such as aggression, gratitude, negotiation of dependency] rather than of the gift itself; (d) it is unhelpful to view gifts simply as "acting out" behavior; (e) relatively few examples of gift-giving were perceived as unhealthy; and (f) it is often difficult to assess the appropriateness of a termination gift because clients seldom return. Here, we have an investigation focused specifically on gifts in therapy, although attention was given only to client gifts to therapists. The types of clients therapists considered in answering the questions is again unknown (see above), and the sample is specific to British and mostly psychoanalytic therapists.

Finally, Knox, Hess, Williams, and Hill (2003) interviewed 12 therapists about their experiences receiving gifts from clients. Participants reported that clients rarely gave them gifts but that all had accepted gifts such as small tokens, handmade items, consumables, or personal items (e.g., perfume). Most participants asserted that addressing gifts was helpful in therapy, that gifts held symbolic value and meaning and were a normal part of human experience, and that they discouraged client gift-giving and considered it a "red flag." They were less likely to accept a gift if it was of high monetary value, was given too early in therapy, seemed related to boundaries, felt manipulative, or evoked an intuitive concern; they were more likely to accept gifts if refusal would be hurtful. When describing specific examples of unproblematic (evoked few concerns for therapists) and problematic (raised concerns for therapists) gifts, the unproblematic gifts they described came primarily from White women in their 30s and 40s who had been in long-term therapy, reflected a range of social classes, and struggled with diverse therapy issues (e.g., family of origin, relationship, and interpersonal concerns). Problematic gifts also came from White women of similar social classes who were addressing similar therapy concerns; however, they ranged in age from 20s to 60s and had less often been in long-term therapy. Problematic gifts were given at more provocative times (e.g., early or midway through therapy) than were unproblematic gifts, and both types of gifts were given for various reasons, including appreciation, manipulation (e.g., to elicit special treatment from the therapist in the case of unproblematic gifts; to induce guilt in the therapist at termination in the case of problematic gifts), and equalization of the

Psychotherapy: Theory, Research, Practice, Training, Vol. 45, No. 1 (March 2008): pg. 103-110. DOI. This article is (C) American Psychological Association and permission has been granted for this version to appear in $\mathrm{e}-$

Publications@Marquette. American Psychological Association does not grant permission for this article to be further copied/distributed or hosted elsewhere without the express permission from American Psychological Association. 
therapy relationship. Both positive and negative internal responses were evoked in therapists by these client gifts, and participants more often discussed unproblematic than problematic gifts with clients. Problematic gifts, however, were more often discussed with others (e.g., colleagues, supervisors) than were unproblematic gifts. Both problematic and unproblematic gift episodes ultimately facilitated the therapy process. In this qualitative study, then, Knox et al. present just the second empirical investigation focused specifically on therapists' experiences of client gifts. Their sample was small, however, and focused only on gifts from adult clients. Although readers are given some information about the clients who gave these therapists gifts, much remains unaddressed (e.g., therapy setting; individual, couples, family, group format).

The sparse extant empirical literature, then, parallels prevailing theoretical and clinical perspectives regarding gifts in therapy. When therapists accept gifts (which are usually small and of minimal financial or emotional value), they do so carefully, often with mixed emotions, weigh in mind a number of factors (e.g., nature and timing of gift, therapy relationship, client diagnosis and demographics, perceived motivation for giving gift), and often discuss the gift and its giving with clients. Gifts from therapists to clients seem to evoke even greater consideration, but similarly small such gifts appear not to be forbidden.

\section{Recommendations for Practice and Research}

Based on both the clinical opinion and the findings of the empirical literature, I offer these recommendations for practice and research regarding gifts in therapy.

\section{Practice Recommendations}

1. Given the lack of empirical investigations about the actual effects, if any, of gifts on the therapy relationship, process, and outcome, it seems imprudent to suggest that therapists fundamentally alter their gift-related behavior. I do suggest, however, that in addition to their seemingly customary discussion with clients about a gift the client may present, they

Psychotherapy: Theory, Research, Practice, Training, Vol. 45, No. 1 (March 2008): pg. 103-110. DOI. This article is (C) American Psychological Association and permission has been granted for this version to appear in e-

Publications@Marquette. American Psychological Association does not grant permission for this article to be further copied/distributed or hosted elsewhere without the express permission from American Psychological Association. 
also talk with clients about how the discussion of the gift process was itself experienced... in a sense, a metadiscussion of the gift interaction between therapist and client. One aspect of such a discussion worthy of consideration is the cultural context from which both client and therapist give and receive gifts. Understanding the norms around gifts in the client's culture, for instance, may prove useful in therapists deciding whether, or how, to accept a gift. Such conversations may thus yield fruitful information, from clients' perspectives, regarding what is experienced as helpful versus neutral versus unhelpful in terms of gift behavior.

2. Therapists giving clients a gift warrants similar discussion. Such events appear to occur less frequently than do gifts from clients to therapists, and thus I encourage therapists to invite clients to share openly their reactions to such events, both over the shortand long-term.

3. In circumstances in which therapists ultimately choose not to accept a client gift, it may be important to follow up on the client's experience of this refusal not only in the immediate aftermath, but also over the longer course of therapy. Amid all that goes on in therapy, the earlier discussion and the gift that elicited it may easily be forgotten on a conscious level, but there may be some residual feelings, for both therapist and client, that merit later attention.

4. For those therapists whose policy is not to accept any client gifts, clear written and spoken communication of this policy with clients as they enter therapy may help avert difficult later interactions around gifts. Similar to informed consent, if clients have an understanding as they begin therapy what the therapist's approach will be, thorny misunderstandings may well be avoided. It should be noted, however, that the intended inhibition of client gifts inherent in such a policy statement may also result in the loss of potentially fruitful discussions between therapists and clients regarding gifts: If clients indeed offer no gifts to therapists, the often illuminating conversations that arise in such exchanges will likely not occur. Therapists must then determine which path seems most prudent for their work with clients. 
NOT THE PUBLISHED VERSION; this is the author's final, peer-reviewed manuscript. The published version may be accessed by following the link in the citation at the bottom of the page.

\section{Research Recommendations}

1. None of the extant studies directly examined the actual effects of gifts on therapy. While a few offered commentary on the perceived effects, these perceptions ultimately had little, if any, empirical basis. Thus, what we know from these studies is in many ways merely an extension of the earlier offered clinical theory regarding gifts in therapy. Clearly, there is a strong need to investigate directly how gifts (whether to or from therapists) may, or may not, affect the therapy relationship, process, and outcome. Until such work is completed, our understanding of gifts in therapy remains fundamentally conjectural.

2. Relatedly, researchers need to examine more closely the process and outcome of gifts in therapy for specific client populations. Sue and Zane (1987) have suggested that cultural factors may influence appropriate gift-related behavior, but no empirical data exist to confirm or deny this assertion. Similarly, do clients with different diagnoses warrant different gift behavior? And though many have commented on the need for different processes regarding gifts with nonadult clients, we again have no evidence to support these claims.

3. Timing of gifts is often mentioned as an important consideration, but again no empirical work currently exists that has examined this factor. How, for example, might a therapist's acceptance or rejection of a gift early versus late in therapy be differentially experienced? Do clients' motivations for offering gifts vary according to time in therapy, and does the meaning with which they imbue the gifts likewise differ? And are different types of gifts offered at different times?

4. To what extent is a discussion in therapy of offered gifts helpful? Most therapists appear to engage in at least some discussion upon receiving a client gift, but how does this discussion really affect clients, therapists, and thus the therapy? And how best should such discussions be approached and proceed? Parallel questions also arise in the case of gifts from therapists to clients.

5. All of the existing studies also examined gifts from the therapist's perspective, thus leaving the client's experiences of such interactions silent. We need, then, to hear what clients 
have to say about their experiences with gifts in therapy (e.g., why, when, how they gave the gift; whether or how the gift was discussed in therapy; the effect of the gift-giving experience on themselves and on therapy).

\section{Conclusion}

In conclusion, although gifts in therapy may not be a frequent occurrence, such events are indeed provocative, for they place both giver and receiver in a potentially delicate situation. While theoretical and clinical perspectives have been offered regarding appropriate giftrelated behavior, there remains surprisingly little empirical research in this area. Here, then, is a ripe opportunity for an exciting integration of science and practice-both researchers and practitioners, and more importantly, clients, may benefit from greater attention to this underexamined topic.

\section{References}

American Psychological Association. (2002). Ethical principles of psychologists and code of conduct. American Psychologist, 57, 1060-1073.

Blanton, S. (1971). Diary of my analysis with Sigmund Freud. New York: Hawthorn Books.

Borys, D. S., \& Pope, K. S. (1989). Dual relationships between therapist and client: A national study of psychologists, psychiatrists, and social workers. Professional Psychology: Research and Practice, 20, 283-293.

Bursten, B. (1959). The expressive value of gifts. American Imago, 16, 437-466.

Freud, S. (1917). On transformations of instinct as exemplified in anal erotism. In J.Strachey (Ed.), The standard ed. of the complete psychological works of Sigmund Freud (Vol. 17). London: Hogarth Press.

Psychotherapy: Theory, Research, Practice, Training, Vol. 45, No. 1 (March 2008): pg. 103-110. DOI. This article is (C) American Psychological Association and permission has been granted for this version to appear in e-

Publications@Marquette. American Psychological Association does not grant permission for this article to be further copied/distributed or hosted elsewhere without the express permission from American Psychological Association. 
NOT THE PUBLISHED VERSION; this is the author's final, peer-reviewed manuscript. The published version may be accessed by following the link in the citation at the bottom of the page.

Gabbard, G. O. (1996). Teacher of the year?Ethics and Behavior, 6, 82-85.

Gartrell, N. K. (1992). Boundaries in lesbian therapy relationships. Women \& Therapy, 12, 29-50.

Gartrell, N. K. (1994). Boundaries in lesbian therapist-client relationships. In B.Greene \& G. M.Herek (Eds.), Lesbian and gay psychology: Theory, research, and clinical applications (pp. 98117). Thousand Oaks, CA: Sage.

Gerson, A., \& Fox, D. (1999). Boundary violations: The gray area. The American Journal of Forensic Psychology, 17, 57-61.

Glover, E. (1955). The technique of psycho-analysis. New York: International Universities Press, Inc.

Gutheil, T. G., \& Gabbard, G. O. (1993). The concept of boundaries in clinical practice: Theoretical and risk-management dimensions. American Journal of Psychiatry, 150, 188-196.

Hahn, W. K. (1998). Gifts in psychotherapy: An intersubjective approach to patient gifts. Psychotherapy, 35, 78-86.

Herlihy, B., \& Corey, G. (1977). Boundary issues in counseling: Multiple roles and responsibilities (pp. 100-109). Alexandria, VA: ACA Press.

Hundert, E. M. (1998). Looking a gift horse in the mouth: The ethics of gift-giving in psychiatry. Harvard Review of Psychiatry, 6, 114117.

Hundert, E. M., \& Appelbaum, P. S. (1995). Boundaries in psychotherapy: Model guidelines. Psychiatry, 58, 345-356.

Knapp, S. J., \& VandeCreek, L. D. (2006). Multiple relationships and professional boundaries. Practical ethics for psychologists: $A$ positive approach (pp. 75-97). Washington, DC: APA.

Psychotherapy: Theory, Research, Practice, Training, Vol. 45, No. 1 (March 2008): pg. 103-110. DOI. This article is (C) American Psychological Association and permission has been granted for this version to appear in ePublications@Marquette. American Psychological Association does not grant permission for this article to be further copied/distributed or hosted elsewhere without the express permission from American Psychological Association. 
NOT THE PUBLISHED VERSION; this is the author's final, peer-reviewed manuscript. The published version may be accessed by following the link in the citation at the bottom of the page.

Knox, S., Hess, S. A., Williams, E. N., \& Hill, C. E. (2003). "Here's a little something for you": How therapists respond to client gifts. Journal of Counseling Psychology, 50, 199-210.

Kritzberg, N. I. (1980). On patients' gift-giving. Contemporary Psychoanalysis, 16, 98-118.

Langs, R. D. (1974). The technique of psychoanalytic psychotherapy (Vol. II). New York: Jason Aronson.

Levin, S., \& Wermer, H. (1966). The significance of giving gifts to children in therapy. Journal of the Academy of Child Psychiatry, $5,630-652$.

Pope, K. S., Tabachnick, B. G., \& Keith-Spiegel, P. (1987). The beliefs and behaviors of psychologists as therapists. American Psychologist, 42, 993-1006.

Roberts, J. (1989). Mythmaking in the land of imperfect specialness: Lions, laundry baskets and cognitive deficits. Journal of Psychotherapy and the Family, 4, 81-110.

Rutan, J. S., \& Stone, W. N. (2001). Psychodynamic group psychotherapy (3rd ed.). New York: Guilford Press.

Ruth, J. A. (1996). It's the feeling that counts: Toward an understanding of emotion and its influence on gift-exchange processes. In C.Otnes \& R. F.Beltramini (Eds.), Gift-giving: A research anthology (pp. 195-214). Bowling Green, OH: Bowling Green State University Popular Press.

Shapiro, E. L., \& Ginzberg, R. (2002). Parting gifts: Termination rituals in group therapy. International Journal of Group Psychotherapy, $52,319-336$.

Simon, R. I. (1989). Sexual exploitation of patients: How it begins before it happens. Contemporary Psychiatry, 19, 104-112.

Smith, L., \& Vannicelli, M. (1985). Co-leader termination in an outpatient alcohol treatment group. Group, 9, 49-56.

Psychotherapy: Theory, Research, Practice, Training, Vol. 45, No. 1 (March 2008): pg. 103-110. DOI. This article is (C) American Psychological Association and permission has been granted for this version to appear in e-

Publications@Marquette. American Psychological Association does not grant permission for this article to be further copied/distributed or hosted elsewhere without the express permission from American Psychological Association. 
NOT THE PUBLISHED VERSION; this is the author's final, peer-reviewed manuscript. The published version may be accessed by following the link in the citation at the bottom of the page.

Spandler, H., Burman, E., Goldberg, G., Margison, F., \& Amos, T. (2000). "A double-edged sword": Understanding gifts in psychotherapy. European Journal of Psychotherapy, Counselling and Health, 3, 77-101.

Stein, H. (1965). The gift in therapy. American Journal of Psychotherapy, 19, 480-486.

Sue, S., \& Zane, N. (1897). The role of culture and cultural techniques in psychotherapy: A critique and reformulation. American Psychologist, 42, 37-45.

Talan, K. H. (1989). Gifts in psychoanalysis: Theoretical and technical issues. Psychoanalytic Study of the Child, 44, 149-163.

\section{Note}

- Sarah Knox, Department of Counseling and Educational Psychology, School of Education, Marquette University.

- I am grateful to Alan W. Burkard and Lewis Z. Schlosser for reading earlier versions of this article.

- Correspondence concerning this article should be addressed to Sarah Knox, Department of Counseling and Educational Psychology, School of Education, Marquette University, Milwaukee, WI 53201. E-mail: sarah.knox@marquette.edu 